\title{
Evaluation of the use of plasma-assisted processes as standard method for supported catalysts production
}

\author{
Avaliação do uso de processos assistidos por plasma como método padrão \\ para produção de catalisadores suportados
}

\author{
Andrey Mello dos Santos ${ }^{1 *}$, Rafael de Camargo Catapan¹, Diego Alexandre Duarte
}

\begin{abstract}
The combination of plasma processes and heterogeneous catalysis for hydrogen production $\left(\mathrm{H}_{2}\right)$ is an innovative green technology, resulting in synergic effects and unique fuel conversion outcomes, such as greater selectivity and lower activation temperature. The present study aims at investigating the feasibility of using plasmaassisted processes as standard technique to produce supported metals catalysts. For this, owing to the higher cost of nickel and cobalt (traditional catalytic metals) compared to other more common metals, iron was selected as testing material. $\mathrm{Fe} / \mathrm{Al}_{2} \mathrm{O}_{3}$ supported catalysts can be applied in dry reforming of methane (DRM), the main component of natural gas.
\end{abstract}

Keywords: Hydrogen, Catalysts, Plasma-assisted processes.

\section{RESUMO}

A combinação de processos de plasma e catálise heterogênea para produzir hidrogênio $\left(\mathrm{H}_{2}\right)$ é uma tecnologia inovadora e limpa de última geração, acarretando em efeitos sinérgicos e resultados únicos de conversão de combustível, tais como maior seletividade e menor temperatura de ativação. O presente estudo visa investigar a viabilidade de uso de processos assistidos por plasma como técnica padrão para produzir catalisadores metálicos suportados. Para isso, devido ao custo superior do níquel e do cobalto (metais catalíticos tradicionais) em comparação com outros metais mais comuns, o ferro foi selecionado como material de teste. Os catalisadores suportados de $\mathrm{Fe} / \mathrm{Al}_{2} \mathrm{O}_{3}$ podem ser aplicados na reforma a seco de metano (RSM), o principal componente do gás natural.

Palavras-chave: Hidrogênio, Catalisadores, Processos assistidos por plasma.

\Universidade Federal de Santa Catarina - Centro Tecnológico de Joinville - Joinville/SC - Brazil.

*Correspondence author: Andrey Mello dos Santos | Universidade Federal de Santa Catarina - Centro Tecnológico de Joinville | Rua Dona Francisca,

8300 | CEP 89.219-600 - Joinville/SC - Brazil

E-mail: andreyms77@gmail.com

Received: Nov. 14, 2018 Approved: Nov. 29, 2018 


\section{INTRODUCTION}

The increasing global demand for energy has led to the extensive use of fossil fuels, resulting in environmental problems, such as air pollution and the accumulation of greenhouse gases in the atmosphere. In this scenario, hydrogen emerges as a promising energy source because it is clean and has high energetic efficiency ${ }^{1,2}$. However, hydrogen is not a primary source of energy, so it is necessary to produce it from other resources ${ }^{3}$. Also, due to its difficult handling, transport and storage, it is necessary to develop techniques to produce this fuel close to where it will be used $^{4}$.

Despite this, hydrogen is an attractive alternative for carbonbased fuels since it can be produced from a variety of renewable resources (biomass, solar, water, geothermal) and non-renewable resources (coal, natural gas, nuclear energy) using energy in the form of electricity or heat ${ }^{5}$. Catalysis is the most widely used method for hydrogen production because it has higher conversion rate and hydrogen selectivity compared to other processes ${ }^{6}$.

Catalysts are being studied to enable onboard hydrogen production in automotive applications. Their function is to modify the kinetics of a chemical process through the reduction of the activation energy (i.e., the minimum energy required for the chemical reaction to occur) without changing the composition and the thermodynamics of the reactions ${ }^{7}$. The role of the catalyst becomes even more important when multiple reactions are thermodynamically viable, as it can determine the dominant reaction pathways, as well as their selectivity, rates, products and energy efficiency ${ }^{8}$.

Previous investigations have shown that noble metals such as platinum (Pt) and rhodium ( $\mathrm{Rh}$ ) have remarkable activity in the catalytic conversion of methane $\left(\mathrm{CH}_{4}\right)$, ethanol $\left(\mathrm{C}_{2} \mathrm{H}_{6} \mathrm{O}\right)$, propane $\left(\mathrm{C}_{3} \mathrm{H}_{8}\right)$ and carbon dioxide $\left(\mathrm{CO}_{2}\right)$ to syngas $\left(\mathrm{H}_{2} \text { and } \mathrm{CO}\right)^{9-11}$. However, high cost and the restricted availability of these metals are major barriers for their use in industrial catalytic applications. Thus, significant attention has been placed on the use of some non-noble transition metal catalysts, especially nickel (Ni) and cobalt (Co) supported catalysts, due to their availability and lower $\operatorname{cost}^{12}$. It is also possible to find in literature studies involving iron (Fe) supported catalysts ${ }^{13,14}$.

Although there are several studies in literature about simultaneous use of plasma and catalysis (also known as plasma assisted catalysis or simply PAC) to convert fossil fuels into $\mathrm{H}_{2}$, few have been studied about the effect of plasma as a synthesis process of catalysts, more specifically to obtain supported metal catalysts. Based on previous studies about plasma treatment of supported catalyst ${ }^{15-18}$, it is believed that plasma-assisted processes can be used as standard method for their production in a simple and effective way. Among them, sputtering stands out as an interesting technique to be used. It is based on the loss of atoms of a surface due to its energetic bombardment by ions ${ }^{19}$.

Under the influence of plasma, nucleation and crystal growth in catalyst preparation can be very different from those in the conventional thermal approach. Some thermodynamically unfavorable reactions can easily take place with plasmas ${ }^{20}$. It is expected many advantages from this alternative technique over the catalysts prepared by traditional methods (impregnation, drying and calcination), such as greater activity, selectivity and durability of the catalyst.

Alumina is commonly used as catalyst support in industrial scale reforming processes and is widely studied for automotive

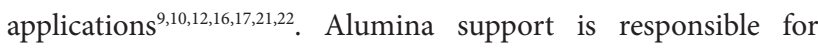
improving catalyst dispersion and for giving resistance to thermal cycling and chemical attacks ${ }^{22}$. In this paper, structural, morphological and chemical properties of $\mathrm{Fe} / \mathrm{Al}_{2} \mathrm{O}_{3}$ supported catalysts, obtained by conventional sputtering, are investigated.

\section{MATERIALS AND METHODS}

Alumina foams with 26 pores $/ \mathrm{cm}, 12.7 \mathrm{~mm}$ thickness and $15 \mathrm{~mm}$ diameter (purchased from Goodfellow) were selected as catalysts support. The samples were fractured and cleaned using an Ultrasonic Cleaner model VR Ultrasonic for $600 \mathrm{~s}$. After this process, foams were putted inside a reactor, as illustrated in Fig. 1, for plasma treatment.

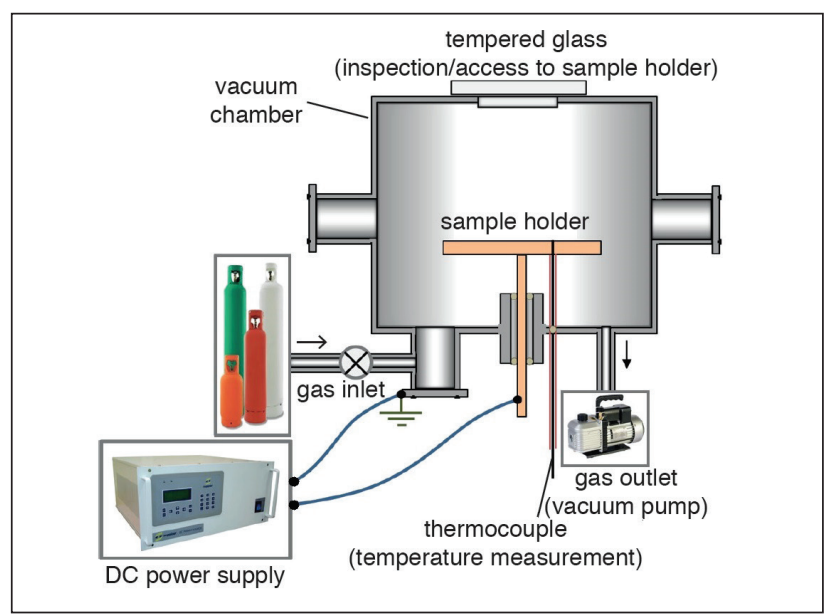

Figure 1: Plasma reactor used for $\mathrm{Fe} / \mathrm{Al}_{2} \mathrm{O}_{3}$ supported catalysts production $^{23}$.

The alumina foam fragments were sputtered in an iron-based substrate (sample holder) in a reactor using $43.4 \mathrm{sccm}$ Ar for $2 \mathrm{~h}$ with temperature of $450{ }^{\circ} \mathrm{C}$, pressure of 0.98 Torr and $650 \pm 12 \mathrm{~V}$ DC. After treatment, it was observed that the samples (originally white) presented a dark layer on the surface, as shown in Fig. 2. During DC discharge, the working gas is ionized. As a result, many positive ions are produced within the chamber and accumulate on the surface of the target (alumina foam) due to its insulating character. Because of this fact, DC discharge is ineffective for sputtering alumina atoms, but is effective to sputter iron atoms from the sample holder, turning it into an interesting alternative for $\mathrm{Fe} / \mathrm{Al}_{2} \mathrm{O}_{3}$ supported catalysts production. Also, DC power supplies are cheap, and the properties of the deposited particles 
depend more of the energy with which the sputtered atoms land on the support surface. This energy can be tuned by the Ar pressure, substrate temperature and bias voltage. Furthermore, the effect of hollow cathode due to the holes present in the substrate helps to increase the rate of sputtering and, consequently, the thickness of the iron layer.

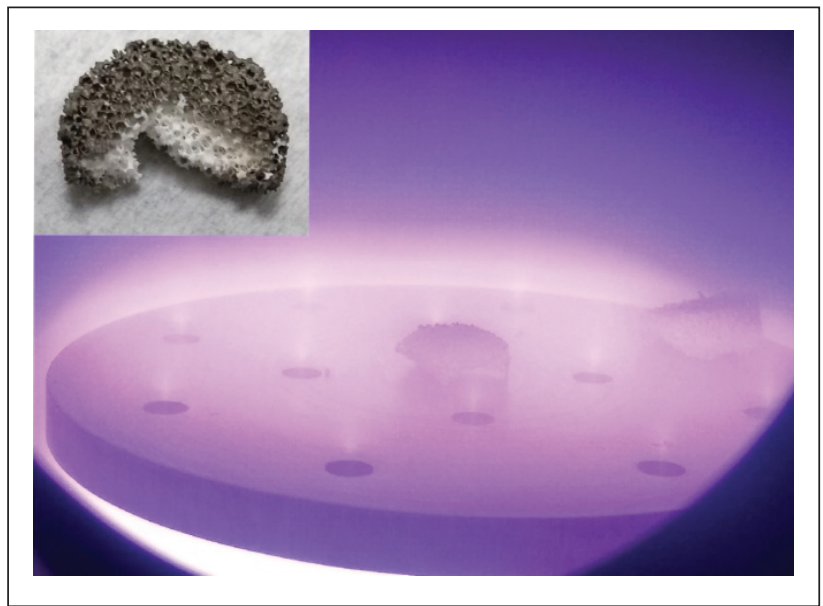

Figure 2: Plasma treatment photo, highlighting the visual aspect of alumina foams fragments after treatment.

Samples with and without plasma treatment were analyzed by $\mathrm{X}$-Ray Diffraction (XRD) using a PANalytical Empyrean with incident $\mathrm{Cu} \mathrm{Ka}$ radiation $(\lambda=1.5406 \AA)$, scan position $2 \theta$ from $20^{\circ}$ to $90^{\circ}$, step size $2 \theta$ of $0.01^{\circ}$ and scan step time of 29 s. These same samples were also morphologically characterized by Field Emission Gun Scanning Electron Microscope (FEG-SEM) using a JSM-6701F with voltage of $15.0 \mathrm{kV}$ and magnification of 40 to $30.000 \times$. For this purpose, samples were previously covered with a thin gold layer to secure the electrical conductivity needed. X-Ray Photoelectron Spectroscopy (XPS) analyses using an SCIENTA OMICRON ESCA + with Al Ka excitation source ( $\mathrm{h} \nu=1486.7 \mathrm{eV})$ and energy step of $0.5 \mathrm{eV}$ were conducted to evaluate chemical properties of the surface, such as oxidation states of elements and chemical interactions.

\section{RESULTS AND DISCUSSIONS}

Results from XRD in Fig. 3 indicate $\alpha-\mathrm{Al}_{2} \mathrm{O}_{3}$ phase for samples before and after plasma treatment ${ }^{24,25}$. Although it is not the best alumina phase for catalytic applications ${ }^{26}$, this is highly used due to its good correlation between catalytic and mechanical properties. Also, by comparing the spectra it is noticed that almost all the peaks had an intensity increase, except the peak located at $80^{\circ}$, after plasma treatment. Indeed, this increase in peaks intensity is probably related to the greater mask diameter used in the analysis of plasma treated samples. However, the intensity increasing of each peak was not the same, which makes it possible to affirm that some cryptographic modifications have occurred.

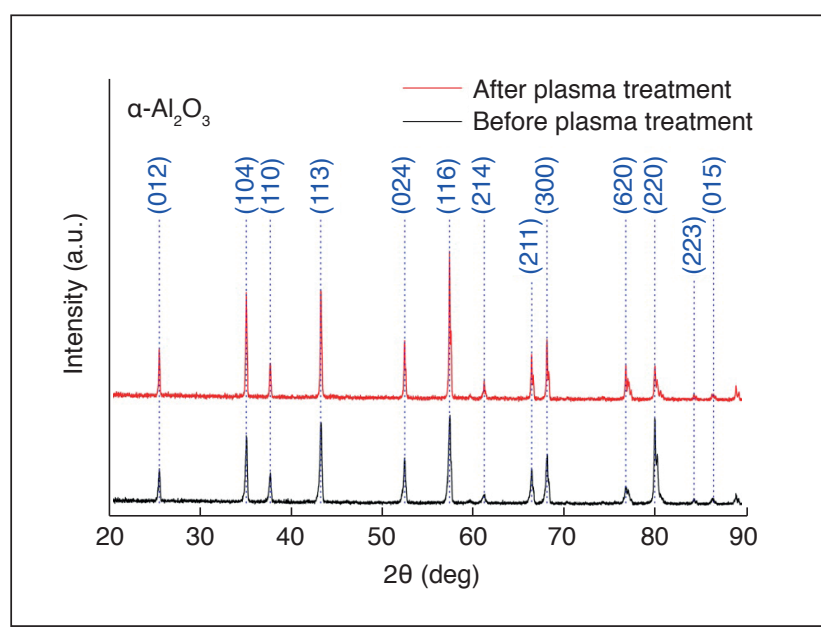

Figure 3: XRD spectra of samples before and after plasma treatment.

In summary, new peaks did not appear after the plasma treatment, and the width of the original sample peaks were not significantly affected. Nevertheless, mean grain size through Scherrer equation was evaluated using data obtained from XRD analyses (Eq. 1):

$$
L=k \lambda / \beta \cos \theta
$$

where $L$ is the crystallite size, $K$ the shape factor (tipically equal $0.9), \lambda$ the X-ray wavelength (1.5406 $\AA$ for $\left.\mathrm{Cu} \mathrm{K}_{\alpha}\right)$, and $\beta$ the peak width at middle high. By this way, it was noticed that plasma treatment tends to increase smoothly the mean grain size, as presented in Table 1.

Table 1: Mean particle size calculated by Scherrer equation based on XRD data.

\begin{tabular}{c|c|c|}
$\begin{array}{c}\text { Measurement } \\
(\mathbf{n m})\end{array}$ & $\begin{array}{c}\text { Before plasma } \\
\text { treatment }\end{array}$ & $\begin{array}{c}\text { After plasma } \\
\text { treatment }\end{array}$ \\
\hline Average & 41.28 & 59.33 \\
\hline Standard deviation & 4.39 & 6.31 \\
\hline
\end{tabular}

The morphology of the samples was analyzed by FEG-SEM images, allowing the verification of the porosity and grains arrangement in the alumina structure. As shown in Fig. 4, the plasma does not affect the macro structure. The sense that the walls of the alumina cellular structure are more enclosed after plasma treatment is only due to the direction of the fracture of the original foam. In addition, the deposited iron layer due to sputtering is very thin, so that it was not even possible to detect it by XRD analyses. Therefore, the overall geometry and density of the pores were preserved.

Analyzing XPS survey spectra from samples before and after plasma treatment, shown in Fig. 5, it is possible to notice that after sputtering a large inelastic peak appears for greater binding energy 


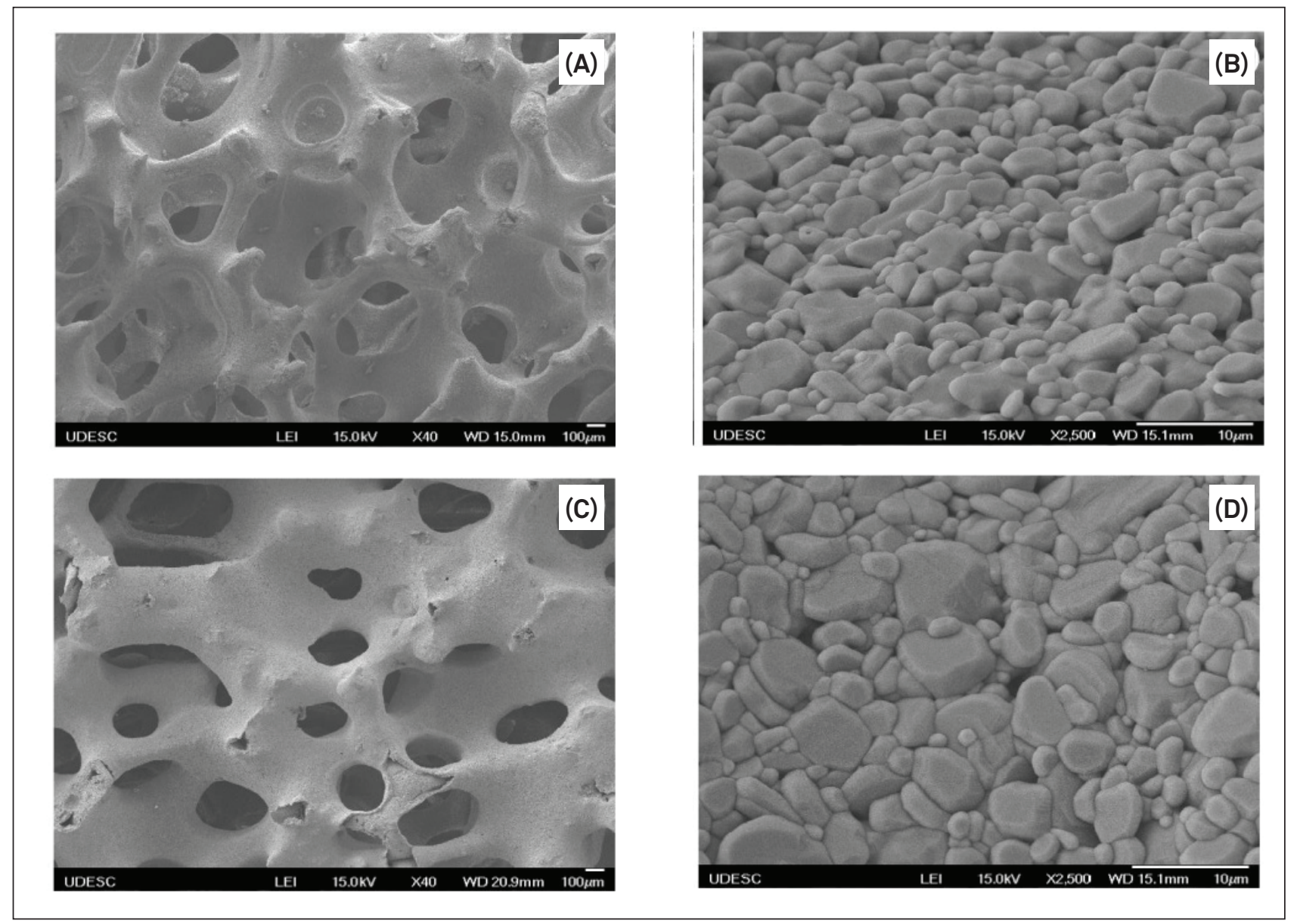

Figure 4: FEG-SEM images from alumina foam (A) before plasma treatment with 40x magnification; (B) before plasma treatment with $2.500 \times$ magnification; $(C)$ after plasma treatment with $40 \times$ magnification; (D) after plasma treatment with $2.500 \times$ magnification.

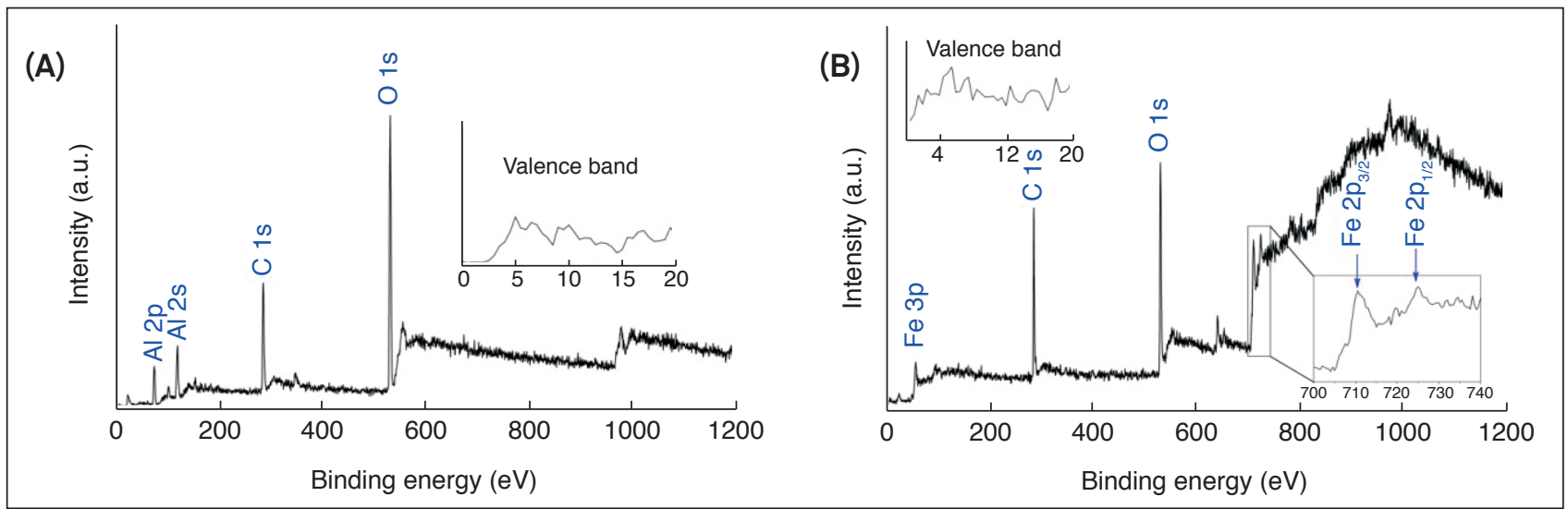

Figure 5: XPS spectra for samples (A) before; (B) after plasma treatment.

values from $707.0 \mathrm{eV}^{27}$. This phenomenon indicates a high number of collisions of the photoelectrons detected and is a characteristic of metallic materials. This result is in agreement with the behavior of the valence bands. For the non-treated sample, a threshold of $2.5 \mathrm{eV}$ is observed to start the photoelectron emission. The opposite occurs with the treated sample, where a metal-like structure is identified (unbound states). This observation, in addition to the XRD results discussed above and the fact that plasma treatment was conducted in a mean temperature of 450
${ }^{\circ} \mathrm{C}$, suggest that iron sputtered from the substrate is only deposited over the alumina fragment surface, creating an amorphous layer of dispersed particles.

The increase of the catalytic activity on the alumina surface is proved from $\mathrm{O} 1 \mathrm{~s}$ orbital, where a concentration of $\mathrm{OH}$ radicals is identified on the covered sample, as depicted in Fig. 6. This chemical state is obtained from water splitting present in the atmosphere. The catalytic surface presents an asymmetrical peak where the lowest side is assigned to $\mathrm{OH}$ radicals and the highest 
one to oxygen from lattice. The surface solely composed by alumina shows a symmetric peak related to oxygen from lattice. Another interesting feature for the covered foam is the shifting of the peak to lower binding energies. The increase of the electrons density caused by $\mathrm{Fe}$ atoms decreases the electrical force on the electrons of the O1s orbital due to the increased electrostatic shielding ${ }^{28}$.

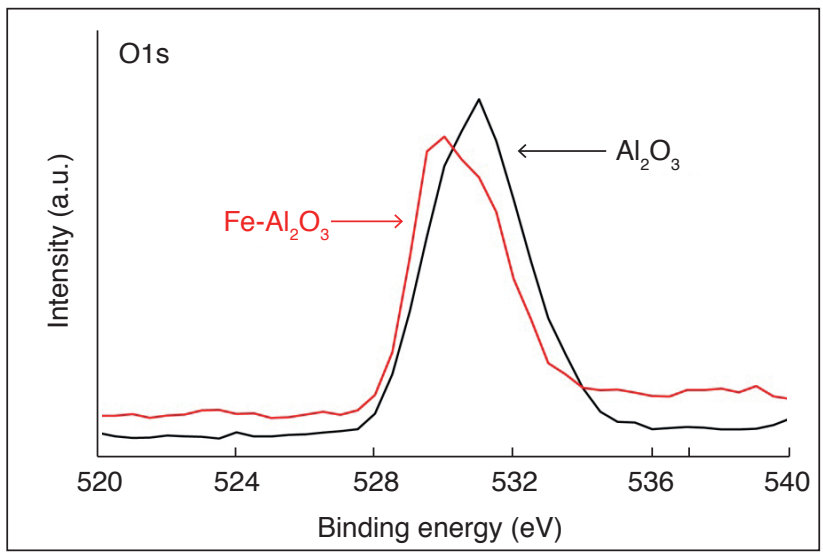

Figure 6: O1s orbital of the treated and non-treated sample.

\section{CONCLUSIONS}

Plasma-assisted processes consist on a simple and efficient technique for supported catalysts production. This same procedure can be used to produce supported metal catalysts of greater catalytic activity and selectivity, such as $\mathrm{Fe} / \mathrm{Al}_{2} \mathrm{O}_{3}, \mathrm{Ni} / \mathrm{Al}_{2} \mathrm{O}_{3}$ and $\mathrm{Co} / \mathrm{Al}_{2} \mathrm{O}_{3}$, which means an alternative process to impregnation, drying and calcination (most common used methods).

\section{ACKNOWLEDGMENTS}

Authors thank the financial support from BMW do Brasil under project UFSC/2016/0110, LPFS/UDESC for plasma treatment and PlasMat/ITA for XRD measurements.

\section{REFERENCES}

1. Nozaki T, Okazaki K. Non-thermal plasma catalysis of methane: principles, energy efficiency, and applications. Catalysis Today. 2013;211:29-38. Available from: https://doi.org/10.1016/j. cattod.2013.04.002

2. Chao $\mathrm{Y}$, Lee $\mathrm{H}$, Chen S, Chang M. Onboard motorcycle plasma-assisted catalysis system - role of plasma and operating strategy. International Journal of Hydrogen Energy. 2009;34(15):6271-6279. Available from: https://doi.org/10.1016/j. ijhydene.2009.05.106

3. Corbo P, Migliardini F, Veneri O. Hydrogen Fuel Cells for Road Vehicles. Green Energy and Technology. London: Springer; 2011.

4. Abdalla AM, Hossain S, Nisfindy OB, Azad AT, Dawood M, Azad AK. Hydrogen production, storage, transportation and key challenges with applications: a review. Energy Conversion and Management. 2018;165:602-627. Available from: https://doi org/10.1016/j.enconman.2018.03.088

5. Edwards PP, Kuznetsov VL, David WIF, Brandon NP. Hydrogen and fuel cells: towards a sustainable energy future. Energy Policy. 2008;36(12):4356-4362. Available from: https://doi.org/10.1016/j. enpol.2008.09.036

6. Du C, Ma D, Wu J, Lin Y, Xiao W, Ruan J, et al. Plasma-catalysis reforming for $\mathrm{H} 2$ production from ethanol. International Journal of Hydrogen Energy. 2015;40(45):15398-15410. Available from: https://doi.org/10.1016/j.ijhydene.2015.09.096

7. Joshi SS, Ranade VV, editors. Industrial Catalytic Processes for Fine and Specialty Chemicals. Amsterdam: Elsevier; 2016.

8. Neyts EC, Ostrikov KK. Nanoscale thermodynamic aspects of plasma catalysis. Catalysis Today. 2015;256, part 1:23-28. Available from: https://doi.org/10.1016/j.cattod.2015.02.025

9. Ayabe S, Omoto H, Utaka T, Kikuchi R, Sasaki K, Teraoka Y, et al. Catalytic autothermal reforming of methane and propane over supported metal catalysts. Applied Catalysis A: General. 2003:241(1-2):261-269. Available from: https://doi.org/10.1016/ S0926-860X(02)00471-4

10. Silberova B, Venvik HJ, Holmen A. Production of hydrogen by short contact time partial oxidation and oxidative steam reforming of propane. Catalysis Today. 2005;99(1-2):69-76. Available from: https://doi.org/10.1016/j.cattod.2004.09.025

11. Corthals S, Witvrouwen T, Jacobs P, Sels B. Development of dry reforming catalysts at elevated pressure: D-optimal vs. ful factorial design. Catalysis Today 2011;159(1):12-24. Available from: https://doi.org/10.1016/j.cattod.2010.06.021

12. Budiman AW, Song S, Chang T, Shin C, Choi M. Dry reforming of methane over cobalt catalysts: a literature review of catalyst development. Catalysis Surveys from Asia. 2012;16(4):183-197. Available from: https://doi.org/10.1007/s10563-012-9143-2

13. Al-Fatesh AS, Fakeeha AH, Ibrahim AA, Khan WU, Atia H, Eckelt $\mathrm{R}$, et al. Decomposition of methane over alumina supported $\mathrm{Fe}$ and $\mathrm{Ni}-\mathrm{Fe}$ bimetallic catalyst: effect of preparation procedure and calcination temperature. Journal of Saudi Chemical Society. 2018;22(2):239-247. Available from: https://doi.org/10.1016/j. jscs.2016.05.001

14. Boubnov A, Lichtenberg H, Mangold S, Grunwaldt J-D. Structure and reducibility of a $\mathrm{Fe} / \mathrm{Al} 2 \mathrm{O} 3$ catalyst for selective catalytic reduction studied by Fe K-edge XAFS spectroscopy. Journal of Physics: Conference Series. 2013;430:012054. Available from: https://doi.org/10.1088/1742-6596/430/1/012054

15. Lee HM, Juan L, Yeh F, Li H, Chen H, Chang MB, et al. Plasmapretreated catalyst for methanol synthesis from syngas. IEEE Transactions on Plasma Science. 2009;37(11):2213-2220. Available from: https://doi.org/10.1109/TPS.2009.2030726

16. Rahemi N, Haghighi M, Babaluo AA, Jafari MF, Estifaee P. CO2 reforming of $\mathrm{CH} 4$ over $\mathrm{CeO} 2$-doped $\mathrm{Ni} / \mathrm{Al} 2 \mathrm{O} 3$ nanocatalyst treated by non-thermal plasma. Journal of Nanoscience and Nanotechnology. 2013;13(7):4896-4908. Available from: https:// doi.org/10.1166/jnn.2013.7585

17. Rahemi N, Haghighi M, Babaluo AA, Jafari MF, Estifaee $P$ Synthesis and physicochemical characterizations of Ni/Al2O3$\mathrm{ZrO} 2$ nanocatalyst prepared via impregnation method and treated with non-thermal plasma for $\mathrm{CO} 2$ reforming of $\mathrm{CH} 4$. Journal of Industrial and Engineering Chemistry. 2013;19(5):1566-1576. Available from: https://doi.org/10.1016/j.jiec.2013.01.024

18. Wang N, Shen K, Yu X, Qian W, Chu W. Preparation and characterization of a plasma treated NiMgSBA-15 catalys for methane reforming with $\mathrm{CO} 2$ to produce syngas. Catalysis Science \& Technology. 2013;3:2278-2287. Available from: https:// doi.org/10.1039/C3CY00299C 
19. Lieberman MA, Lichtenberg AJ. Principles of Plasma Discharges and Materials Processing. Hoboken: John Wiley \& Sons; 2005.

20. Wang Z, Zhang Y, Neyts EC, Cao X, Zhang X, Jang BW, et al. Catalyst Preparation with Plasmas: How Does It Work? ACS Catalysis. 2018;8(3):2093-2110. Available from: https://doi. org/10.1021/acscatal.7b03723

21. Lee J, Jang EJ, Kwak JH. Acid-base properties of Al2O3: effects of morphology, crystalline phase, and additives. Journal of Catalysis. 2017;345:135-148. Available from: https://doi. org/10.1016/j.jcat.2016.11.025

22. Shang Z, Li S, Li L, Liu G, Liang X. Highly active and stable alumina supported nickel nanoparticle catalysts for dry reforming of methane. Applied Catalysis B: Environmental. 2017;201:302309. Available from: https://doi.org/10.1016/j.apcatb.2016.08.019

23. Scholtz JS, Batschauer AL, Mezaroba M, Fontana LC. Increasing the plasma current through improvement of secondary electrons emission in CCP-plasmas by using a new asymmetric bipolar plasma power supply (ABIPPS). In: XXXIX Congresso Brasileiro de Aplicações de Vácuo na Indústria e na Ciência; Oct. 08-11; Joinville, Brazil; 2018.
24. RRUFF. Powder Diffraction and Cell Refinement of Al2O3. RRUFF database; [accessed 2018 August 04]. Available from: https:// bit.ly/2Mjmfhi

25. Yazdani B, Xu F, Ahmad I, Hou X, Xia Y, Zhu Y. Tribological performance of graphene/carbon nanotube hybrid reinforced Al2O3 composites. Scientific Reports. 2015;5:11579. Available from: https://doi.org/10.1038/srep11579

26. Andersson JM. Controlling the formation and stability of alumina phases [PhD Thesis]. Linköping: Linköping University; 2005.

27. Pereira CAM, Abbate M, Schreiner WH, Boff MAS, Teixeira $\mathrm{SR}$, Schmidt JE. Electronic structure of granular $\mathrm{Fe}-\mathrm{Al} 2 \mathrm{O} 3$ thin films prepared by co-evaporation. Solid State Communications. 2000;116(8):457-460. Available from: https://doi.org/10.1016/ S0038-1098(00)00346-X

28. Chen X, Burda C. Photoelectron spectroscopic investigation of nitrogen-doped titania nanoparticles. J. Phys. Chem. B. 2004;108(40):15446-15449. Available from: https://doi. org/10.1021/jp0469160 